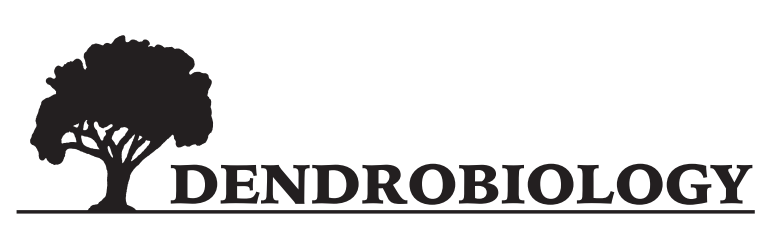

2017, vol. 77, 33-43

http://dx.doi.org/10.12657/denbio.077.003

\author{
Robert Kalbarczyk, Monika Ziemiańska*
}

\title{
Identification of meteorological conditions in the growth of Robinia pseudoacacia on the basis of pointer years in urban conditions
}

\begin{abstract}
This study assessed changes in air temperature and rainfall during the growth of black locusts (Robinia pseudoacacia L.) in urban conditions in the city of Wroclaw based on pointer years. Materials consisted of 54 wooden discs taken from felled straight-trunked trees at a height of $1.3 \mathrm{~m}$ from the ground at four sampling sites in the area of a defunct garden established at the turn of the $20^{\text {th }}$ century. Meteorological indicators were calculated based on monthly data obtained from the Wroclaw meteorological station, part of the national atmospheric monitoring network. Tree ring widths were determined using LINTAB 6 and TSAP-Win software. A set of meteorological elements describing temperature and rainfall conditions during the growth of the black locusts significantly affecting the tree ring widths, were selected using cluster analysis. Pointer years were defined as the years when a unidirectional change (e.g. an increase) in tree ring width compared to a previous year was observed in at least $75 \%$ of the trees. In the multiannual period 1955-2014 we found seven pointer years, comprising three positive years (tree ring wider than in the year before): 1986, 1989, 1996, and four negative years (tree ring narrower than in the year before): 1963, 1983, 1990,1991 . The width of the tree rings were formed under the influence of different unique thermal and rainfall systems each year. Within the groups of positive and negative pointer years, individual months differed in the impact of air temperature and rainfall conditions on tree ring widths.
\end{abstract}

Keywords: air temperature, rainfall, dendroclimatology, tree ring width, black locusts

Addresses: R. Kalbarczyk, Division of Engineering and Landscape Protection, Landscape Architecture Institute, Faculty of Environmental Engineering and Geodesy, Wroclaw University of Environmental and Life Sciences, Grunwaldzka 55 Street, 50-357 Wroclaw, POLAND, mail: robert.kalbarczyk@up.wroc.pl M. Ziemiańska*, Division of Engineering and Landscape Protection, Landscape Architecture Institute, Faculty of Environmental Engineering and Geodesy, Wroclaw University of Environmental and Life Sciences, Grunwaldzka 55 Street, 50-357 Wroclaw, POLAND, mail: monika.ziemianska@up.wroc.pl

\section{Introduction}

The impact of natural and anthropogenic factors on the growth of tree species may be assessed by the dynamics of tree ring width variation in a multiannual period. However, the description of the general relationships between the environment and tree ring widths in urban conditions is difficult due to the climatic differences between cities (Cedro et al., 2011; Rashidi et al., 2012; Cedro \& Nowak, 2015; Kalbarczyk \& Ziemiańska, 2016). In addition, the tree ring width is shaped not only by the natural aging trend, individual variability of the tree and anthropogenic factors, but also by meteorological 
conditions (Feliksik et al., 2007; Feliksik \& Wilczyński, 2008; Kutnar \& Kobler, 2013) which come as an entire set of simultaneous factors (GarcíaSuárez et al., 2009). In addition, weather conditions may indirectly determine the variability of tree ring widths through their impact on the appearance, spreading and activity and herbivorous insects and parasitic fungi, as well as the occurrence of seed years (Okoński et al., 2014a).

Due to this complexity, the relationship between the weather and tree ring widths is most clearly marked in years with extreme weather conditions (De Ridder et al., 2014). The evaluation of the role of weather conditions in the growth of trees is based on the analysis of pointer years, i.e. when tree ring widths in all or most of the surveyed trees at a given site are greater or smaller than in the previous year (Cedro, 2012). A pointer year may sometimes be the same for different species (Okoński et al., 2014b), and its territorial range may cover not only a single site, but also a region or even an entire continent (Pourtahmasi et al., 2007; Bronisz et al., 2012; Rybníček et al., 2012; De Ridder et al., 2014). Analysis based on pointer years makes it possible to evaluate the course of meteorological conditions in a given year, characterized by a unique combination of conditions, in contrast to statistical analyses that evaluate the relationship between weather and tree ring widths over a multi-year period (Wilczyński, 2004). Therefore, the aim of this study was to use pointer years to determine changes in air temperature and rainfall during the growth of black locusts in urban conditions in the city of Wrocław.

\section{Materials and methods}

The research material was collected at the site of a former garden from the turn of the $20^{\text {th }}$ century in Pilczycka street $\left(\phi 51^{\circ} 08^{\prime} 27^{\prime \prime} \mathrm{N}, \lambda 16^{\circ} 57^{\prime} 25^{\prime \prime} \mathrm{E}, \mathrm{Hs}=\right.$ $116.3 \mathrm{~m}$ above sea level) in the northwestern part of Wroclaw (a city in south-western Poland). The discs cut from the black locust were obtained during a planned felling of the trees due to regrowth of the land. Analysis concerned 54 discs taken at a height of $1.3 \mathrm{~m}$ from the ground. The study used discs from stands selected according to the EKO strategy (Bronisz et al., 2012). Before analyzing the width of the annual tree rings, the discs surfaces were dried and planed, and then filtered water was used to enhance the contrast between the rings. Measurements of tree ring widths were performed in duplicate on the East-West directions of bark to core and core to bark with the use of the LINTAB ${ }^{\text {TM }}$ 6 and TSAP-Win software, to a precision of 0.01 $\mathrm{mm}$. LINTAB ${ }^{\mathrm{TM}}$ is a standard tool used by other researchers for measuring the tree ring widths (Motta et al., 2009; Köse \& Günter, 2012; De Ridder et al., 2014; Jansons et al., 2015; Sensuła et al., 2015). The obtained biometric measurements for each of 54 trees in question served to determine individual sequences of tree ring widths, constituting a chronologically arranged series of tree ring widths, which were then assigned WP codes (with numbers from 1 to 54 ). The study did not include the last, incomplete tree rings from 2015, as the discs were obtained in late March and early April. Assessment of the correctness of the synchronization of annual and individual tree ring widths was conducted with the use of COFECHA software which tested each data series in relation to the established standard chronology and compared the Pearson's correlation coefficients (Holmes, 1986; Koprowski, 2006; Poljanšek et al., 2012). Sequences that were the least similar to the standard pattern in the site included WP2, WP12, WP25, WP49, WP50, WP51 and WP53 were excluded from further analysis (Bijak, 2013). ARSTAN software was used to create raw data chronology, indexed chronology by the elimination of the trend and long-term fluctuations, and highlighting the short-term variations, and residual chronology by removing autocorrelations from the series of tree ring indexes (Cook \& Holmes, 1999; Poljanšek et al., 2012; Rybníček et al., 2012).

Data on monthly air temperatures $\left(\mathrm{Ta},{ }^{\circ} \mathrm{C}\right)$ and rainfall levels (Rf, mm) in the period 1954 to 2014 were collected from the Wroclaw weather station (IMGW-PIB), part of the national atmospheric monitoring network.

The raw-data, indexed and residual chronologies of the black locust were described using basic statistical indicators: the arithmetic mean $(\overline{\mathrm{x}}, \mathrm{mm})$, minimum ( $\min , \mathrm{mm})$ and maximum ( $\max , \mathrm{mm}$ ), standard deviation ( $\mathrm{sd}, \mathrm{mm}$ ), coefficient of variation $(\mathrm{V}, \%)$, autocorrelation coefficient $\left(\mathrm{I}^{\circ}, \mathrm{rw}\right)$ and Pearson's correlation coefficient determined for the linear trend. In addition, we calculated mean sensitivity $\left(\overline{\mathrm{x}}_{\mathrm{s}} \mathrm{mm}\right)$ which describes the degree of difference between the consecutive values in a time series (Zielski, 1997). We also established expressed population signal (EPS), a criterion for the fidelity with which a chronology constructed using increment widths from a sample of a population expresses the common environmental forcing in the whole population (Wigley et al., 1984).

Cluster analysis was used to select a set of meteorological elements describing thermal $(\mathrm{Ta})$ and rainfall (Rf) conditions during the growth of black locust, that is, from June of the year preceding the formation of the tree ring to September in the year of the tree ring formation. Thus selected period allowed to take into account the impact of the previous growing season and winter dormancy (Fritts, 1976). Before analysis, all the input data were 
standardized in order to be able to compare the distributions of many variables and many groups, as well as to make the tested variables independent from the units of measure. Measurements were clustered with $k$-means non-hierarchical clustering. The optimal number of clusters was determined by a cross-validation $v$-test. The significance of differences between the clusters was evaluated based on the analysis of variance using Fisher's exact test at $\alpha$ $\leq 0.05$

We established pointer years with at least a $75 \%$ minimum threshold of compliance, which means that tree ring widths in most of the trees at the site were wider (positive year) or narrower (negative year) than in the previous year (Kędziora \& Tomusiak, 2012). We also determined the incidence of wider and narrower tree ring widths compared to the preceding year in the invidual sequences of black locusts by successive years of the analyzed multi-year period 1955-2014 in three classes: 50\% (small change), from $50 \%$ to $75 \%$ (average change) and $\geq 75 \%$ (large change).

We also showed the temporal distribution of air temperature and rainfall in the period from June of the preceding year to September of the tree ring formation, and evaluated those meteorological elements against the multi-year period 1955-2014 for each pointer year, separately for positive and negative years. Months of the current year were labelled with consecutive Arabic numerals $(1,2 \ldots 9)$, and the number of months preceding the formation of the tree ring were additionally described by the letter $\mathrm{p}(6 \mathrm{p}, 7 \mathrm{p} \ldots 12 \mathrm{p})$.

\section{Results}

\section{Site chronology}

Of the 54 analyzed black locust sequences, the two oldest sequences were 90 years old, which resulted in a site chronology (TRW) of 1925-2014 (Fig. 1). A large group of 29 sequences was aged 61-65 years, 18 samples were over 66 years old, and only 7 samples were aged no more than 50 years.
Tree ring widths in the raw data chronology 19252014 were very diverse, ranging from $1.06 \mathrm{~mm}$ to $8.42 \mathrm{~mm}$ (Fig. 2, Table 1). The mean tree ring width for the raw-data chronology was $2.62 \mathrm{~mm}$, standard deviation $1.59 \mathrm{~mm}$, and the coefficient of variation $\sim 61 \%$. The average sensitivity was $0.14 \mathrm{~mm}$ and did not differ from the values determined for other site chronologies of deciduous tree species growing in this part of Europe (Bronisz et al., 2012; Jansons et al. 2015). The EPS index for the raw-data chronology (TRW) was 0.95 , higher than the minimum threshold shown by Wigley et al. (1984).

The raw-data chronology time structure was characterized by a significantly negative age related trend, which meant that the year-on-year increases in tree ring widths were ever smaller $(r=-0.79, \alpha$ $<0.01$ ), as well as a significantly positive first order autocorrelation coefficient $(\mathrm{rp}=0.807, \alpha<0.01$ ) (Table 1). The raw-data chronology time series conversion into a standard chronology was accompanied by a removal of linear trend $(r=0.018, \alpha>$ 0.1 ), while conversion into residual chronology was associated with the additional removal of first order autocorrelation ( $\mathrm{rp}=0.015, \alpha>0.1)$.

\section{The impact of sets of temperature and rainfall conditions on tree ring widths}

The distinguished 3 clusters in the period 19552014 allowed characterizing the sets of weather conditions which favored different widths in the raw-data chronology (Fig. 3). The analysis of variance showed that all the examined variables describing the thermal and rainfall conditions during the growth of the black locusts significantly differentiated the established clusters $(\alpha \leq 0.01)$. The highest values of Fisher exact tests were calculated for the air temperature in December of the year preceding formation of the tree rings, and then for the rainfall in February, and the air temperature in January (Table 2). Therefore, these three meteorological indicators had the greatest influence on tree ring widths in the raw-data chronology. A slightly weaker influence on raw-data chronology, yet still

Table 1. Statistical characteristics of the site chronology of black locusts with WP codes. Years 1925-2014

\begin{tabular}{|c|c|c|c|c|c|c|c|c|c|}
\hline \multirow{3}{*}{ Chronology } & \multicolumn{9}{|c|}{ Characteristics } \\
\hline & $\bar{x}$ & $\bar{x} s$ & $\min$ & $\max$ & sd & \multirow{2}{*}{$\begin{array}{c}\mathrm{V} \\
(\%)\end{array}$} & \multirow{2}{*}{ EPS } & \multirow{2}{*}{$\begin{array}{l}\text { ror linear } \\
\text { trend }\end{array}$} & \multirow{2}{*}{$\begin{array}{l}\text { first-order auto- } \\
\text { correlation (rp) }\end{array}$} \\
\hline & & & $(\mathrm{mm})$ & & & & & & \\
\hline Raw-data & 2.62 & 0.14 & 1.06 & 8.42 & 1.59 & 60.6 & 0.95 & $-0.79 * * *$ & $0.807^{* * *}$ \\
\hline Standard & 1.01 & 0.12 & 0.33 & 1.71 & 0.21 & 20.5 & 0.91 & $0.018 \mathrm{~ns}$ & $0.637 * * *$ \\
\hline Residual & 1.00 & 0.13 & 0.57 & 1.56 & 0.15 & 15.0 & 0.83 & $0.028 \mathrm{~ns}$ & $0.015 \mathrm{~ns}$ \\
\hline
\end{tabular}

$\bar{x}$ - average, $\bar{x}_{s}$ - average sensitivity, min - the lowest value in the time series, max - the highest value in the time series, sd - standard deviation, $\mathrm{v}$ - coefficient of variation, $\mathrm{r}$ - correlation coefficient, ${ }^{* * *}-$ significant at $\alpha<0.01$, ns - nonsignificant at $\alpha<0.1$. 


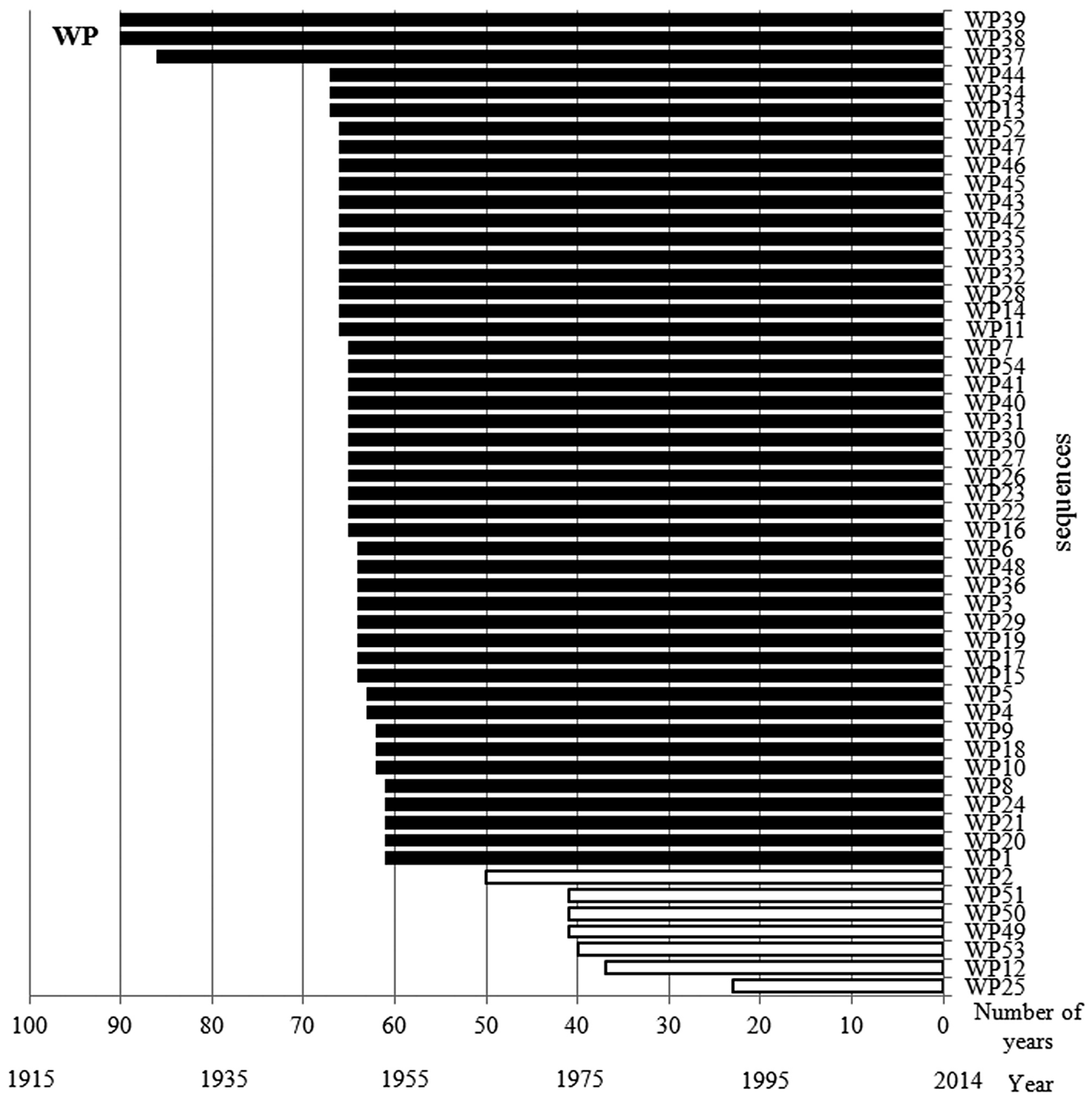

Fig. 1. A comparison of dendrochronologically dated sequences of tree ring widths of black locusts. forming a site chronology with the WP code, arranged by age. $\square$-sequences excluded from further statistical analysis

significant at $\alpha \leq 0.01$, was exerted by rainfall in April and July, and air temperature in February.

Clusters 1 and 2 were characterized by raw-data chronology tree ring widths lower than for the entire group of studied trees; by 0.1 and $0.3 \mathrm{~mm}$, respectively (Table 3 ). Cluster 3 , covering 20 years, clustered air temperature and rainfall accompanying the widest raw-data chronology average, exceeding the mean tree ring width of the raw-data chronology by about $0.4 \mathrm{~mm}$, the raw-data chronology average being $1.9 \mathrm{~mm}$ in the years 1955-2014. Cluster 3 , with the widest average annual tree ring widths, was characterized by above-average air temperature in December in the year preceding the formation of the ring, as well as moderate (compared to other clusters) air temperature in January and February. In addition, the wider tree ring widths correlated with below-average rainfall in February and above-average rainfall in April and July, which means that large rainfall in those months contributed to the increase in the raw-data chronology.

\section{Pointer years}

In the multi-year period 1955-2014, a period in which the number of trees analyzed was the same (47), we established pointer years. During the period of 60 years we identified only 7 pointer years, 


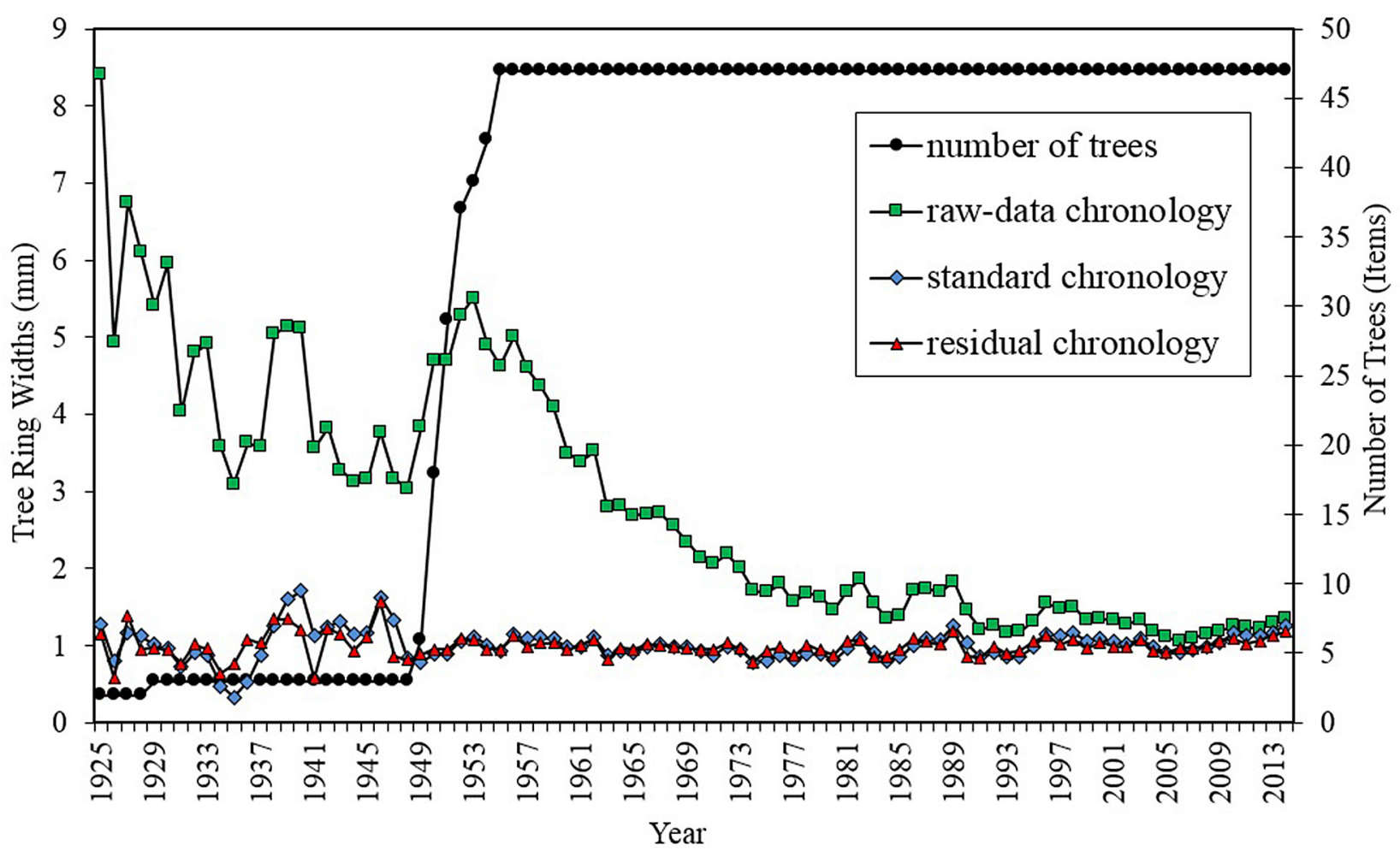

Fig. 2. The course of site chronology of black locusts with the WP codes in the years 1925-2014

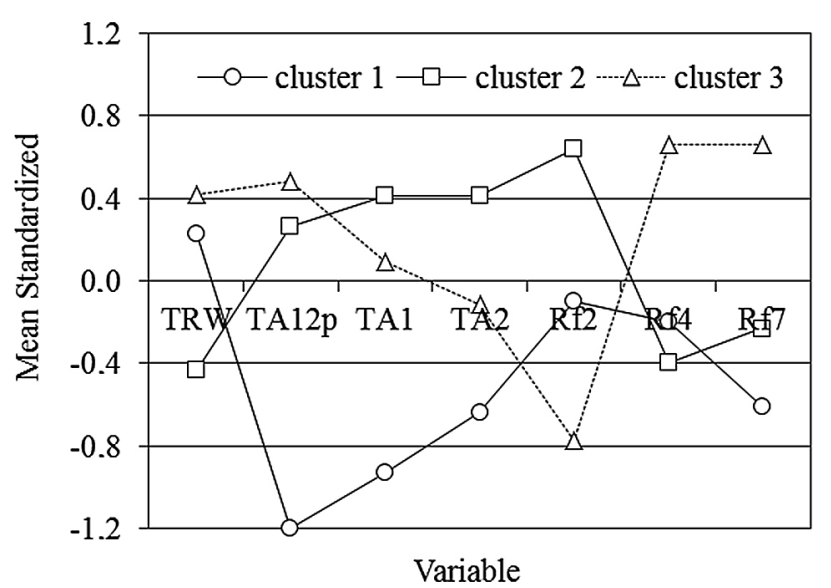

Fig. 3. Standardized means of six meteorological elements describing the tree ring widths of the site chronology of black locusts with WP codes (TRW) for individual clusters $(1,2,3)$. Ta - air temperature $(1-$ in January, 2 - in February, 12 - in December), Rf - rainfall (2 - in February, 4 - in April, 7 - in July), p - previous year

which means that every 8-9 years tree ring widths in at least $75 \%$ of black locusts at the analyzed site in Wroclaw were wider or narrower when compared to the previous year (Fig. 4). Of the 7 pointer years, 3 were positive $(1986,1989,1996)$, with wider rings in
Table 2. Statistical evaluation of clusters established on the basis of thermal and rainfall conditions in the period $1955-2014$

\begin{tabular}{lrrrrrr}
\hline & \multicolumn{5}{c}{ Statistical characteristics } \\
\cline { 2 - 7 } $\begin{array}{c}\text { Varia- } \\
\text { ble }\end{array}$ & SS & DfSS & SSE & DfSSE & $\begin{array}{r}\text { Fish- } \\
\text { er's } \\
\text { test }\end{array}$ & $\alpha$ \\
\hline TRW & 9.6 & 2 & 50.4 & 58 & 5.5 & 0.01 \\
Ta12p & 27.2 & 2 & 32.8 & 58 & 24.0 & 0.01 \\
Ta1 & 17.1 & 2 & 42.9 & 58 & 11.6 & 0.01 \\
Ta2 & 10.8 & 2 & 49.2 & 58 & 6.4 & 0.01 \\
Rf2 & 23.6 & 2 & 36.4 & 58 & 18.8 & 0.01 \\
Rf4 & 13.8 & 2 & 46.2 & 58 & 8.7 & 0.01 \\
Rf7 & 15.0 & 2 & 45.0 & 58 & 9.7 & 0.01 \\
\hline
\end{tabular}

$\mathrm{SS}$ - sum square error of between-group variation, $\mathrm{Df}_{S S}-$ number of degrees of freedom for sum square error SS, SSE - sum square error of within-group variation, $\mathrm{Df}_{\mathrm{SSE}}-$ number of degrees of freedom for sum square error SSE, $\alpha-$ level of significance. Other symbols as in Fig. 3.

most of the trees, and 4 were negative $(1963,1983$, 1990 and 1991).

The greatest agreement of results was shown for 1996 , when $\sim 87 \%$, i.e. 40 out of the 47 analyzed trees, had greater tree ring widths than in the previous year (Fig. 4). At a lower threshold of only $\geq$ $60 \%$, the pointer years would rise in number to 23 , including 9 positive and 14 negative years. 
Table 3. Statistical characteristics $(\mathrm{x} \pm \mathrm{sd})$ of thermal and rainfall conditions determined for each cluster and for the complete set of data describing the tree ring widths

\begin{tabular}{|c|c|c|c|c|c|c|c|c|}
\hline \multirow{3}{*}{$\begin{array}{l}\text { number } \\
\text { of the } \\
\text { cluster }\end{array}$} & \multirow{3}{*}{$\begin{array}{l}\text { the number of } \\
\text { observations in } \\
\text { the cluster }\end{array}$} & \multirow{3}{*}{ TRW } & \multicolumn{6}{|c|}{ Characteristics } \\
\hline & & & \multicolumn{3}{|c|}{$\left({ }^{\circ} \mathrm{C}\right)$} & \multicolumn{3}{|c|}{$(\mathrm{mm})$} \\
\hline & & & Ta12p & Ta1 & Ta2 & $\mathrm{Rf2}$ & Rf4 & Rf7 \\
\hline 1 & 14 & $1.8 \pm 0.7$ & $-2.5 \pm 2.1$ & $-4.3 \pm 3.2$ & $-2.6 \pm 2.1$ & $24.3 \pm 11.4$ & $34.5 \pm 13.5$ & $62.4 \pm 38.7$ \\
\hline 2 & 26 & $1.6 \pm 0.8$ & $1.1 \pm 1.5$ & $0.1 \pm 2.4$ & $1.1 \pm 2.5$ & $34.2 \pm 10.4$ & $30.2 \pm 14.4$ & $83.6 \pm 33.9$ \\
\hline 3 & 20 & $2.3 \pm 1.3$ & $1.6 \pm 2.0$ & $-0.9 \pm 2.9$ & $-0.7 \pm 4.5$ & $16.1 \pm 8.7$ & $49.6 \pm 19.6$ & $124.1 \pm 53.7$ \\
\hline$\Sigma 1-3$ & 60 & $1.9 \pm 1.0$ & $0.4 \pm 2.4$ & $-1.2 \pm 3.2$ & $-0.3 \pm 3.5$ & $26.0 \pm 12.7$ & $37.6 \pm 18.0$ & $92.0 \pm 48.1$ \\
\hline
\end{tabular}

TRW - tree ring widths in raw-data. Other symbols as in Fig. 3.

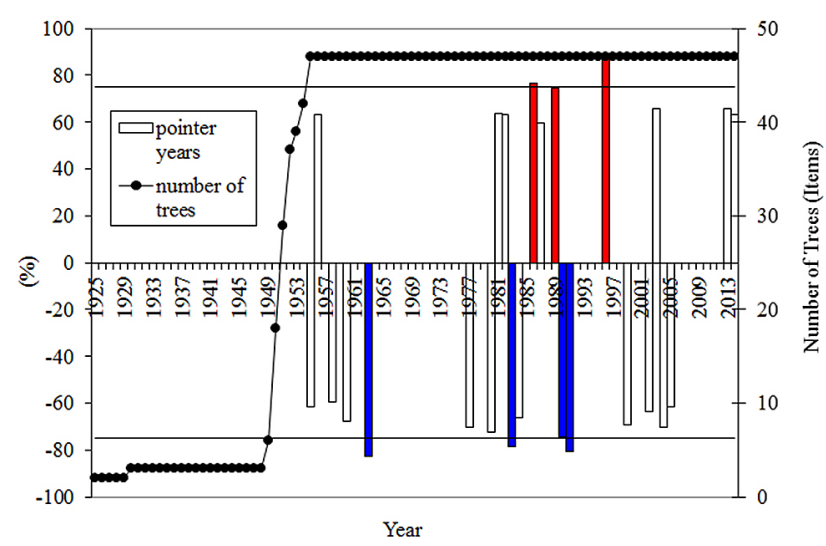

Fig. 4. The incidence ( $>60 \%$ ) of unidirectional changes in tree ring widths in the site chronology of black locusts with the WP codes. Positive $(\square)$ and negative $(\square)$ pointer years established for the multiannual period 1955-2014

\section{Structure of year-on-year changes in incidence of tree ring widths and in temperature and rainfall conditions}

In the individual years of the analyzed multi-annual period, the tree ring widths in 47 trees showed a diversity of changes compared to the preceding year (Fig. 5). Approx. $52 \%$ of tree rings were narrower than in the preceding year compared to $\sim 48 \%$ for the proportion of wider rings. Changes in tree ring widths compared to the previous year showed a certain diversity. The narrower tree rings were most frequently only slightly different $(\sim 43 \%)$, with the much lower incidence of moderate and large decreases ( $\sim 5 \%$ and $4 \%$, respectively). $\sim 47 \%$ rings were slightly wider, while only $\sim 1 \%$ moderately wider, and we recorded no large increases (i.e. those at least $75 \%$ greater than in the preceding year). During the established positive pointer years 1986 and 1989, in $73-75 \%$, the tree ring increase in width was low, and only in $\sim 2 \%$ were they moderate. In the pointer year $1996 \sim 87 \%$ of all trees saw small increases in tree ring widths compared to the preceding year. In the negative pointer years, the majority of trees had narrower rings than in the preceding year, albeit with certain differences. In these years, the most frequently observed changes were small $(\sim 45-58 \%)$, then intermediate $(\sim 11-20 \%)$ and large $(9-13 \%)$.

In the years 1955-2014 the thermal and rainfall conditions in the study area were characterized by high variations (Fig. 6). Long-term average air temperature in the period from June of the year preceding the formation of the ring to September of the current year was $10.7^{\circ} \mathrm{C}$ and ranged from $9.1^{\circ} \mathrm{C}$ in 1963 to $12.9^{\circ} \mathrm{C}$ in 2007 . During that period the air temperature increased significantly $\left(0.3^{\circ} \mathrm{C} / 10\right.$ years, $\alpha \leq$ 0.01 ). The average sum of rainfall in the 15 -month period stood at $\sim 865 \mathrm{~mm}$; the lowest was $591.4 \mathrm{~mm}$ in 2004, and the highest 1174 in 1977. In the pointer years the temperature and rainfall conditions also varied. For instance, in 1986, in the 15-month period, the air temperature was $9.7^{\circ} \mathrm{C}$ and rainfall 943.5 $\mathrm{mm}$, whereas in 1990 it was $11.6^{\circ} \mathrm{C}$ and $617.9 \mathrm{~mm}$, respectively.

\section{Thermal and rainfall conditions in the established pointer years}

The air temperature in the period 1955-2014, in periods from June of the year preceding the formation of tree rings in black locust and September in the year of tree ring formation, ranged from $1.1^{\circ} \mathrm{C}$ in January to $18.5^{\circ} \mathrm{C}$ in July (Fig. 7ab). In 3 positive pointer years: 1986, 1989, 1996 and in the years immediately preceding pointer years, the air temperature in June and November of the preceding year and in July of the ring formation was lower than normal (1955-2014), which means that wider rings correlated with lower temperatures. In negative 4 pointer years (1963, 1983, 1990 and 1991), above-average air temperatures in August resulted in the formation of tree rings narrower than in the previous year. In the remaining months, the effect of air temperature was not clear, which means that the narrower rings were accompanied by both higher and lower temperatures than normal. For example, in 1963 narrower rings were formed at temperatures lower than the long-term average, while in 1990 at temperatures higher than the long-term average (for the period from December to March). 


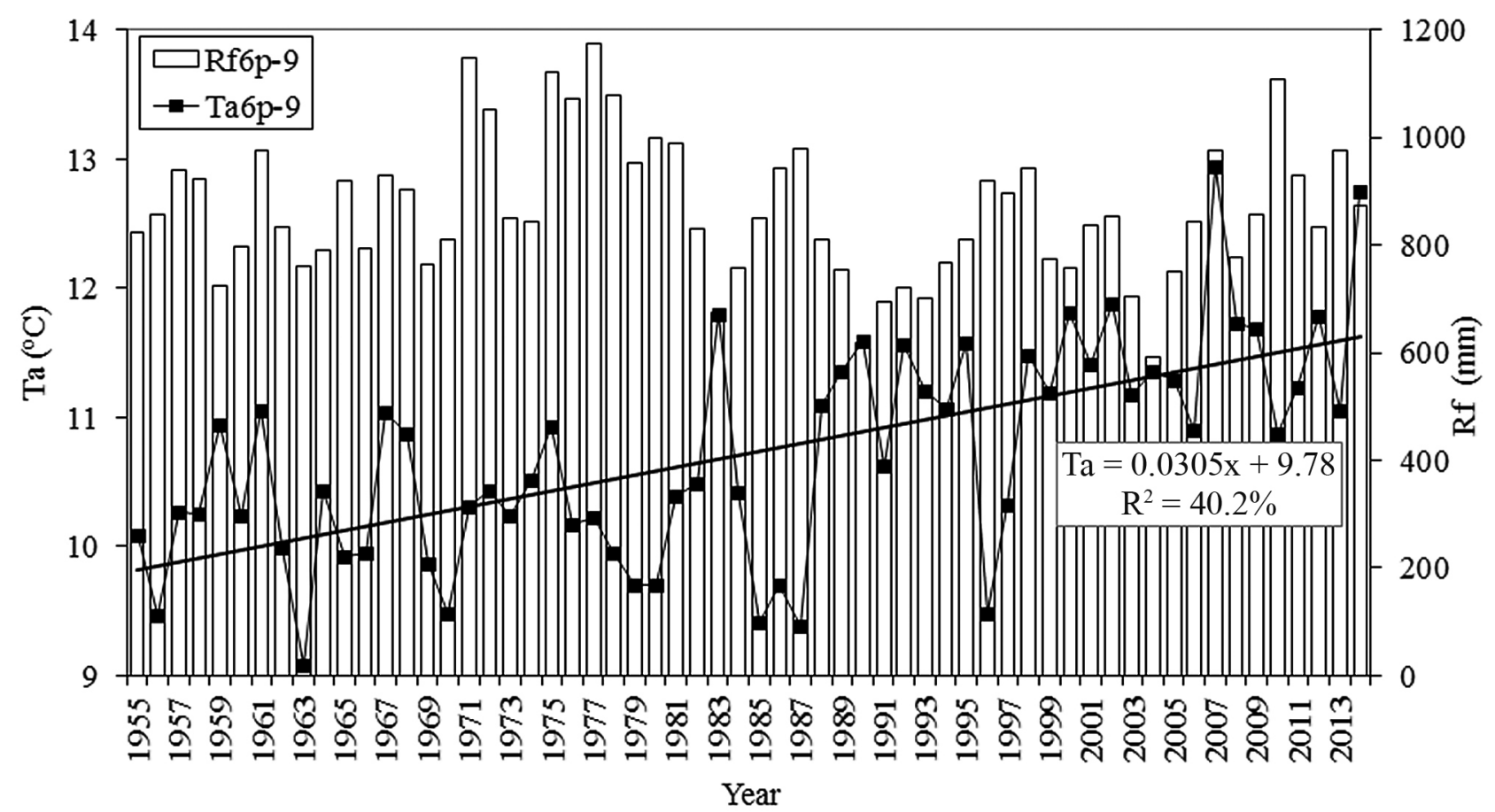

Fig. 6. Temporal distribution of air temperature and rainfall during the growth and growth of black locust, from June of the year preceding the ring formation to September of the ring formation year, in the period 1955-2014. Other symbols as in Fig. 3

During the period of the growth of black locust (i.e. 15 months), the rainfall also showed some differentiation (Fig. 7cd). The greatest sum of rainfall was $91 \mathrm{~mm}$ (July), the smallest was $26 \mathrm{~mm}$ (February). We found a greater number of regularities between raw-data chronology and rainfall than between raw-data chronology and thermal conditions. Years with rings wider than in the preceding years were preceded by above-average rainfall in June of the previous year (e.g. in 1996 it was even $\sim 220 \%$ of normal) and below-average rainfall in July and October of the preceding year, and in February-March in the year of ring formation (e.g. in February 1986 it was only $\sim 33 \%$ of the long-term average). During negative pointer years, the structure of rainfall was different than in the positive pointer years, since above-average rainfall was recorded in June of the year of ring formation (e.g. in 1983 as much as $\sim 148 \%$ of longterm average), and below-average in July and during September-October of the previous year (e.g. in September 1983 only 19\% of long-term average), and in March and July-August period of the current year (e.g. in July 1963 only $\sim 22 \%$ of long-term average).

\section{Discussion}

In Poland, few dendroclimatic and dendrometric studies have concerned the black locust (Feliksik et al., 2007; Stolarski et al., 2013; Klisz et al., 2014). Such studies have also been rare in other countries, and it is difficult to compare them with our research due to differences in climate and location (Klašnja et al., 2000; Adamopoulos \& Voulgaridis 2002; Motta et al., 2009; Adamopoulos et al., 2010). The statistical indicators determined in our research $\left(\overline{\mathrm{x}}, \overline{\mathrm{x}}_{\mathrm{w}}\right.$ min, max, sd, V), describing the site chronology of the black locust in Wroclaw, differed significantly from indicators for other site chronologies of deciduous trees in this part of Europe (Klašnja et al., 2000; Feliksik et al., 2007; Jansons et al., 2015).

We showed a significant effect of air temperature (Ta12p, Ta1, Ta2) and rainfall (Rf2, Rf4, Rf7) on TRW. Such ambiguous reactions of tree ring widths to temperature during dormancy (from December of the previous year to February) may be directly associated with the specific predispositions of this species (non-native in Poland) and a wide range of tolerance to habitat and climatic conditions. Similar results were obtained by Feliksik et al. (2007), who showed a significant influence of temperature and rainfall on tree ring widths, including air temperature in January-April (Ta1-4) and rainfall in July-August (Rf78). According to Feliksik et al. (2007), cold winters and low temperatures in the first months of the year (January-April), and the low rainfall in summer, especially in June and July, are the factors that most strongly negatively influence the tree ring widths in black locust. Rainfall in February-April may have a long-term effect - the replenishment of water in the soil and higher groundwater level (Jaworski, 2004). Spring replenishment of water allows plants 
a)

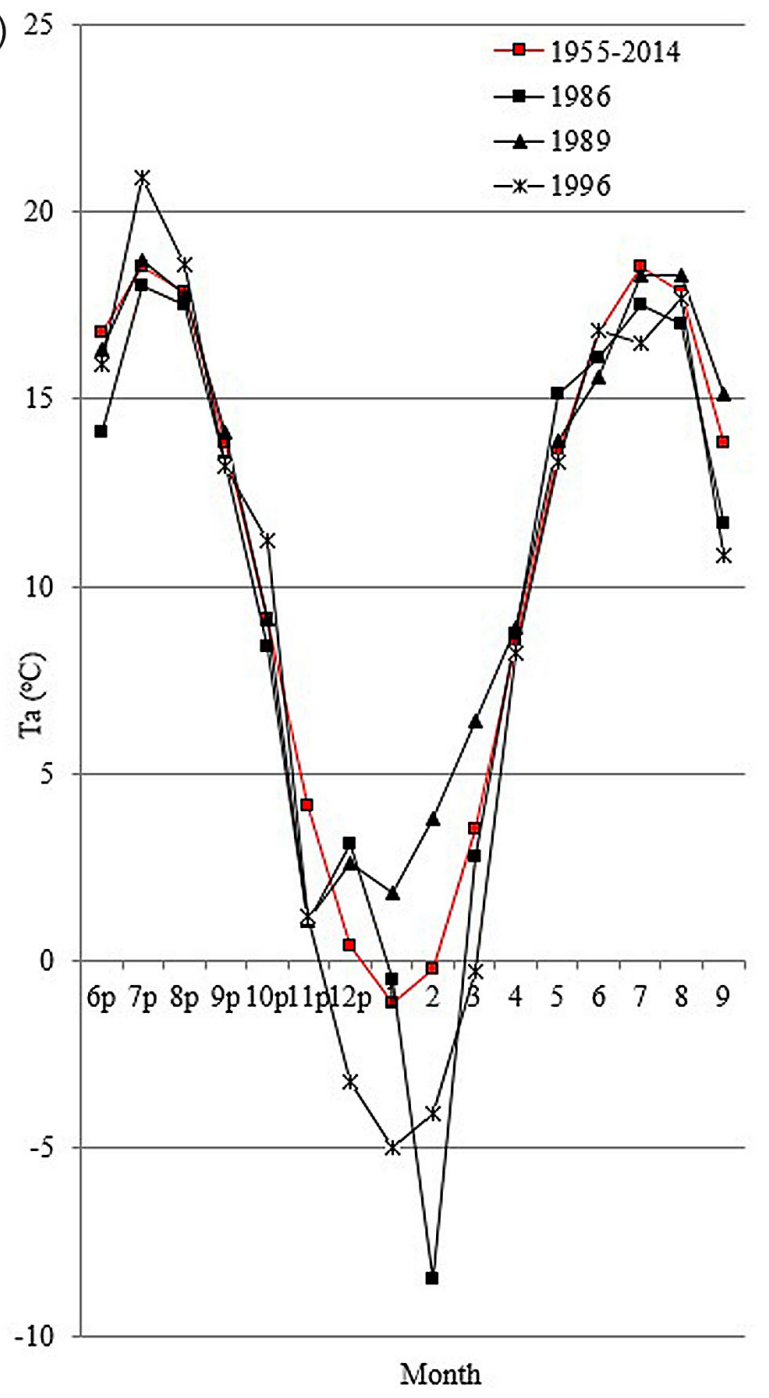

c)

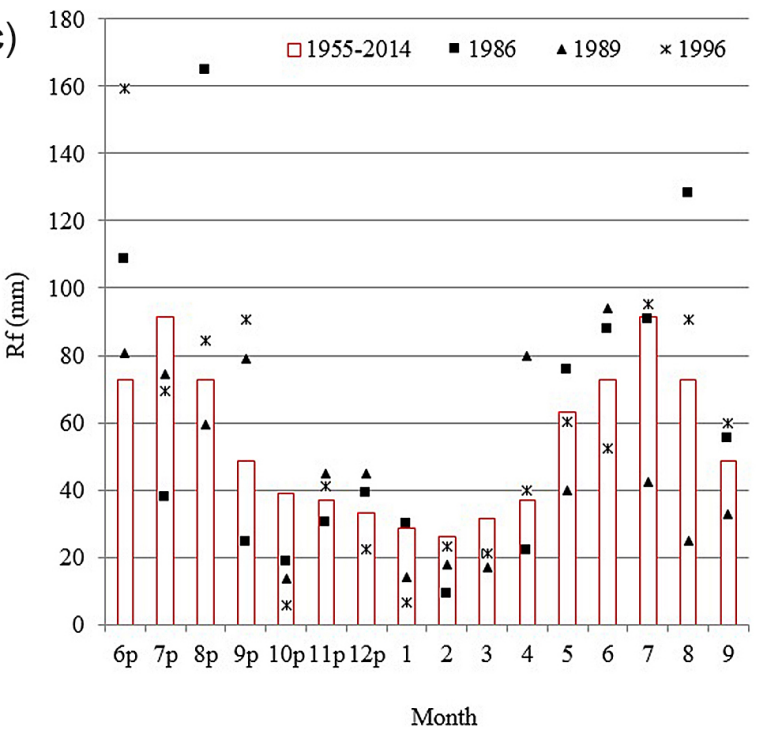

b)

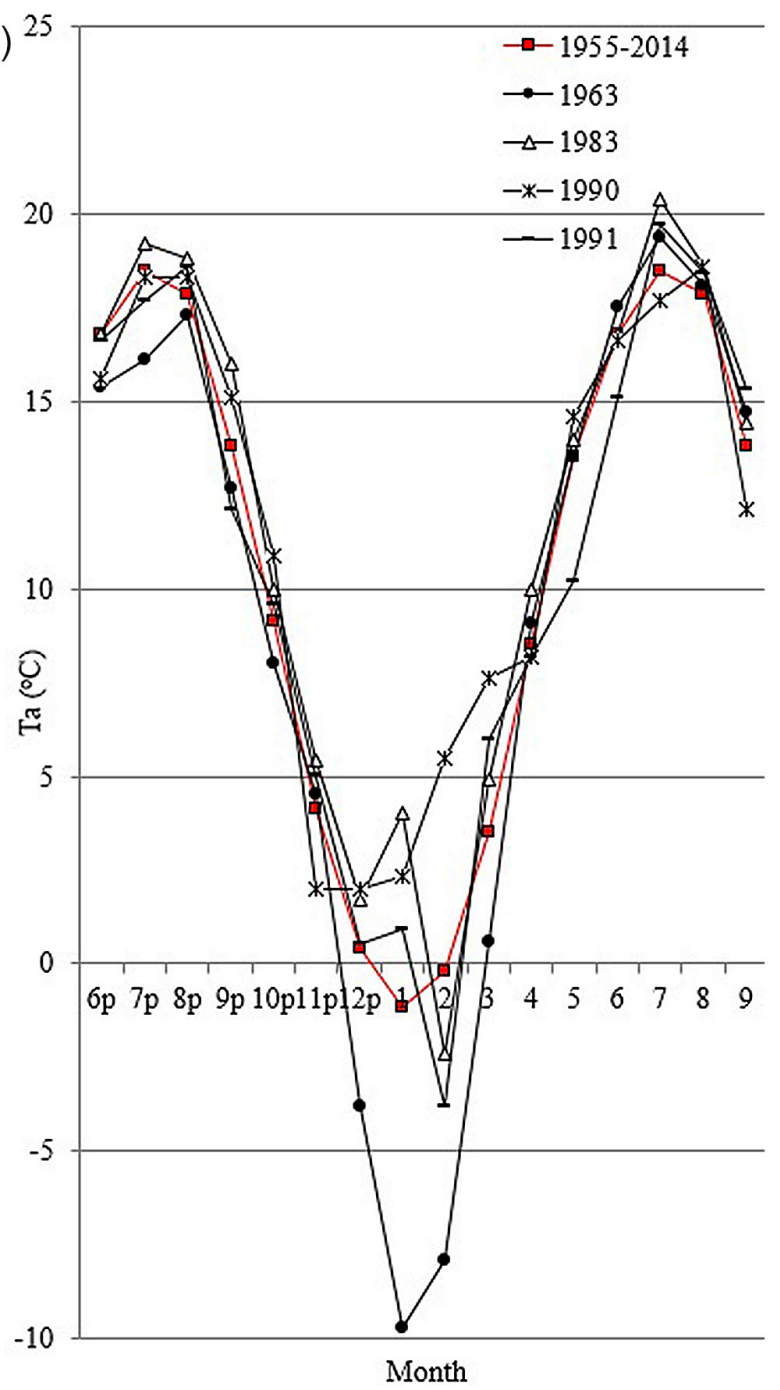

d)
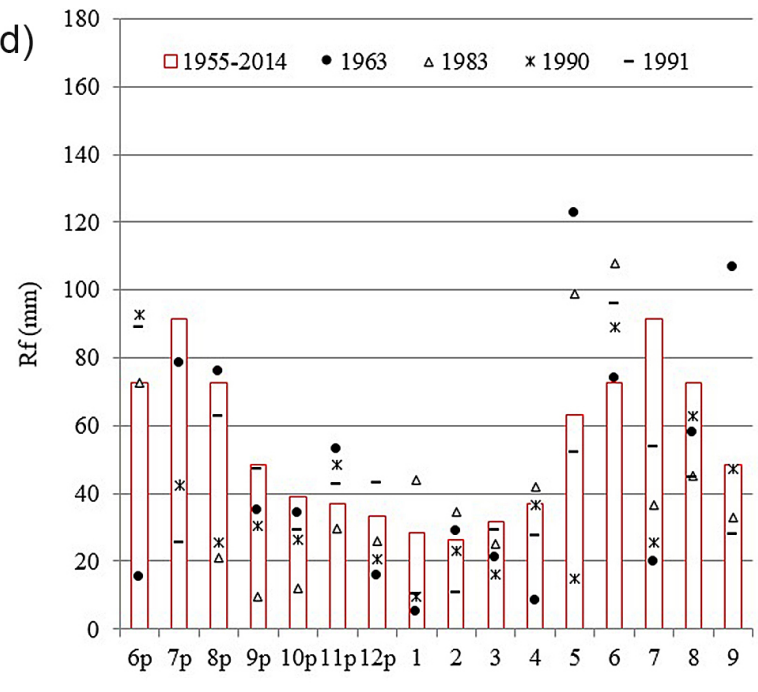

Month

Fig. 7. Thermal and rainfall conditions in the positive (a, c) and negative (b, d) pointer years (for the period January - 1 to September -9 ), and in the years immediately preceding the pointer years (between June $-6 p$ to December $-12 p$ ) on a multi-year period 1955-2014 
to tolerate periodic shortages of rainfall during the growing season. This has a direct relationship with the pace and quality of biochemical processes in the trees, as well as photosynthesis and the regulation of transpiration. Most likely, the impact of the July rainfall on increases in the tree ring widths of different tree species is very significant because of dwindling groundwater resources, which are already exhausted at this stage of the growing season. Therefore, in July the growth of trees often depends on the use of surface water coming from rainfall. July droughts adversely affected the length of the shoots and tree ring widths in the trees, and so high rainfall in July, amounting to $126 \%$ of normal, significantly positively influenced the annual growth of black locust in the years 1955-2014, and contributed to its proper growth.

Literature gives various limits for pointer years, usually ranging from $60 \%$ to $90 \%$ of trees (Feliksik \& Wilczyński 2004; Poljanšek et al., 2012). The threshold value depends, among others, on the tree species, location, or the size of the tested sample (Wilczyński, 2004; Wilczyński \& Szymański 2014). Although the pointer year 1990 was also negative for oaks throughout Estonia (Sohar et al., 2014), and the years 1963 and 1983 were also negative for common beech in north-eastern Poland (Koprowski, 2006), pointer years rarely occur simultaneously in different species of trees, even under similar conditions. It sometimes happens that pointer years are different in the case of trees of the same species but growing at different sites (Bronisz et al., 2012). The negative pointer years established by other scientists, e.g. 1963 and 1983 by Koprowski (2006), based on the annual increase in tree ring widths in common beech in Poland, or 1990 by Sohar et al. (2014) for the tree ring widths of pedunculate oak in Estonia, were also heavily dependent on thermal and rainfall conditions, similar to our results for the years 1955-2014. Narrower rings of those tree species, formed in the years 1963, 1983 and 1990, were determined by a very dry period of May-July, or June, which is similar to tree rings of black locust, affected by a very dry period of July-August (Fig. 7). Those three pointer years established by others (1963, 1983 and 1990), and 1991, were the years of deep droughts across almost the entire Poland (Łabędzki, 2007; Kalbarczyk, 2010).

\section{Conclusions}

Site chronology of black locust growing in the urban conditions of the city of Wroclaw was characterized by a significantly negative senile trend $(-0.54$ $\mathrm{mm} / 10$ years, $\alpha \leq 0.01$ ), and its tree ring widths ranged from $1.06 \mathrm{~mm}$ (2006) to as much as 8.42 $\mathrm{mm}$ (1925). Among the analyzed meteorological elements of thermal and rainfall conditions, tree ring widths were most influenced by air temperature in December in the year preceding the formation of rings (Ta12p), as well as January (Ta1) and February (Ta2), and by rainfall in February (Rf2), April (Rf4) and July (Rf7) of the year of ring formation. In the analyzed multiannual period, we established 7 pointer years, including three positive years $(1986,1989$, 1996) and four negative years $(1963,1983,1990$, 1991), which means that every 8-9 years tree ring widths in at least $75 \%$ of black locusts were wider or narrower when compared to the previous year. In the selected years pointer years, the courses of air temperature and rainfall varied and were different from the long-term structure. Within the groups of positive and negative pointer years, the individual months differed in the impact of changes in air temperature and rainfall conditions on tree ring widths. In pointer years, tree rings that were wider than in the previous year were formed by air temperatures (in months: Ta6p, Ta11p, Ta7) and rainfall (in months: Rf7p, Rf10p, Rf2 and Rf3) below long-term averages (1955-2014). Only rainfall in June (Rf6p) was higher than the long-term average.

\section{Acknowledgements}

This research was supported by Dean of Faculty of Environmental Engineering and Geodesy at Wroclaw University of Environmental and Life Sciences Professor Bernard Kontny.

\section{References}

Adamopoulos S, Chavenetidou M, Passialis C \& Voulgaridis E (2010) Effect of cambium age and ring width on density and fibre length of black locust and chestnut wood. Wood Research 55(3): 25-36.

Adamopoulos S \& Voulgaridis E (2002) Within-tree variation in growth rate and cell dimensions in the wood of clack locust (Robinia pseudoacacia L.). IAWA Journal 23(2): 191-199.

Bijak Sz (2013) Climat signal in the radial growth of selected coniferous species from the forest Experimental Station in Rogów. Leśne Prace Badawcze 74(2): 101-110.

Bronisz A, Bijak Sz, Bronisz K \& Zasada M (2012) Climate influence on radial increment of Oak (Quercus sp.) in Central Poland. Geochronometria 39(4): 276-284.

Cedro A \& Nowak G (2015) Dendroclimatic investigations on Quercus rubra and Quercus robur in north-western Poland. Dendrobiology, 74: 123133 
Cedro A, Nowak G \& Zieliński J (2011). The impact of climate conditions on the width of annual increments at the maidenhair tree (Ginkgo biloba L.) in urban conditions of Szczecin (NW Poland). Plant Diversity and Evolution 129(3-4): 229-240.

Cedro A (2012) Dendrochronologia cisa pospolitego w Polsce i na zachodniej Ukrainie. PPH ZAPOL Dmochowski, Sobczyk, Szczecin, Poland

Cook ER \& Holmes RL (1999) Program ARSTAN chronology development with statistical analysis (User's manual for program ARSTAN). Laboratory of Tree-Ring Research University of Arizona, $18 \mathrm{pp}$.

De Ridder M, Toirambe B, Van den Bulcke J, Bourland N, Van Acker J \& Beeckman H (2014) Dendrochronological potential In semi-deciduous rainforest: the case of Pericopsis elata in Central Africa. Forests 5: 3087-3106.

Feliksik E \& Wilczyński S (2004) Signature years of Douglas fir (Pseudotsuga menziesii (Mirb.) Franco) in Poland. Sylwan 12: 39-47

Feliksik E, Orzeł S \& Wilczyński S (2007) Dendrometric and dndroclimatological analyses of Black Locust. EJPAU 10(2), \#07.

Feliksik E \& Wilczyński S (2008) Tree-ring chronology as a source of information on susceptibility of sitka spruce to climatic conditions of Pomeranian (northern Poland). Geochronometria 30: 79-82.

Fritts HC (1976) Tree rings and climate. The Blackburn Press Caldwell, New Jersey, USA.

García-Suárez AM, Butler CJ \& Baillie MGL (2009). Climate signal in tree-ring chronologies in a temperate climate: a multi-species approach. Dendrochronologia 27: 183-198.

Holmes RL (1986) Quality control of cross dating and measuring. User's manual for computer program COFECHA. In: Holmes R L, Adams RK, Fritts HC. Tree-ring chronologies of Western North America: California, Eastern Oregon and northern Great Basin. Laboratory of Tree-Ring Research, University of Arizona, Tucson, Chronology Ser. 6: 41-49.

Jansons A, Matisons R, Purin, L, Neimane U \& Jansons J (2015) Relationships between climatic variables and tree-ring width of European beech and European larch growing outside of their natural distribution area. Silva Fennica 49, 1 article id 1255.

Jaworski A (2004) Podstawy przyrostowe i ekologiczne odnawiania oraz pielęgnacji drzewostanów. PWRL, Warszawa, Poland, pp. 69

Kalbarczyk R (2010) Temporal and spatial diversity of the occurrence of atmospheric drought in Poland (1966-2005) and its effect on yield of pickling cucumber (Cucumis sativus L.). Spanish Journal of Agricultural Research 8(4): 1147-1162.
Kalbarczyk R \& Ziemiańska M (2016). The effect of air temperature, precipitation and humidity on ring widths in the black locust (Robinia pseudoacacia L.) growing in urban conditions. Wood Research 61 (3):351-362.

Kędziora W \& Tomusiak R (2012). Dendrochronological analysis of radial increments of English oak (Quercus robur L.) in Mazury Landscape Park. Studia i Materiały CEPL w Rogowie R. 14, z. 1 (30): 29-36.

Klašnja B, Kopitović Š, Orlović S \& Galić Z (2000) Variability of some structural and physical properties of Black Locust (Robinia pseudoacacia L.) wood. Genetika 32(1): 9-17.

Klisz M, Ukalska J, Wojda T, Jastrzębowski Sz, Mionskowski M \& Szyp-Borowska I (2014) Radial growth of selected stands of black locust in Poland. Annals WULS - SGGW, Forestry and Wood Technology 85: 123-130.

Kutnar L \& Kobler A (2013) The current distribution black locust (Robinia pseudoacacia L.) in Slovenia and predictions for the future. Acta Silvae et Ligni 102: $21-30$.

Koprowski M (2006) Dendrochronological analysis of European beech (Fagus sylvatica L.) tree rings in the Iława Forest District. Sylwan 5: 44-50.

Köse N \& Günter HT (2012) The effect of temperature and precipitation on the intra-annual radial growth of Fagus orientalis Lipsky in Artvin, Turkey. Turkish Journal of Agriculture and Forestry 36: 501-509

Łabędzki L (2007) Estimation of local drought frequency in central Poland using the standardized precipitation index SPI. Irrigation and Drainage System 56(1): 67-77.

Motta R, Nola P \& Berretti T (2009) The rise and fall of the black locust (Robini pseudoacacia L.) in the „Siro Negri” Forest Reserve (Lombardy, Italy): lessons learned and future uncertainties. Annals of Forest Science 66, 410.

Okoński B, Miler AT, Czerniak A, Grajewski S \& Duszyński P (2014a) Impact of black arches (Lymantria monacha L.) outbreak on radial increment of scots pine (Pinus sylvestris L.) in the Puszcza Notecka forest. Studia i Materiały CEPL w Rogowie R. 16, z. 39 (2B): 103-109.

Okoński B, Koprowski M, Danielewicz W, Miler AT \& Kasztelan A (2014b) Application of pointer years to assess the effect of river regime on growth conditions of trees in the Warta river valley. Studia i Materiały CEPL w Rogowie R. 16, z. 30(3): 154-164.

Poljanšek S, Ballian D, Nagel TA \& Levanič T (2012) A 435-year-long European black pine (Pinus nigra) chronology for the central-western Balkan Region. Tree-Ring Res 68(1): 31-44. 
Pourtahmasi K, Parsapajouh D, Bräuning A, Esper J \& Schweingruber FH (2007) Climatic analysis of pointer years in tree-ring chronologies from northern Iran and neighboring high Mountain areas. Geokodynamik 28: 27-42.

Rashidi F, Jalili A, Kafaki SB, Sagheb-Talebi K \& Hodgson J (2012) Anatomical responses of leaves of Black Locust (Robinia pseudoacacia L.) to urban pollutant gases and climatic factors. Trees 26: 363-375.

Rybníček M, Čermák P, Kolář T \& Žid T (2012) Growth responses of Norway spruce (Picea abies (L.) Karst.) to the climate in the south-eastern part of the Českomoravská Upland (Czech Republic). Geochronometria 39(2): 149-157.

Sensuła B, Opała M, Wilczyński S \& Pawełczyk S (2015) Long- and short-term incremental response of Pinus sylvestris L. from industrial area nearby steelworks in Silesian Upland, Poland. Dendrochronologia 36: 1-12

Sohar K, Läänelaid A, Eckstein D, Helama S \& Jaagus J (2014) Dendroclimatic signals of pedunculate oak (Quercus robur L.) in Estonia. European Journal of Forest Research 133: 535-549.

Stolarski MJ, Krzyżaniak M, Szczukowski S, Tworkowski J \& Bieniek A (2013) Dendromass derved from agricultural land as energy feedstock. Polish Journal of Environmental Studies 22(2): 511-520.

Wigley TML, Briffa KR \& Jones PD (1984) On the average value of correlated times, with applications in dendroclimatology and hydrometeorology. Journal of Climate and Applied Meteorology 23:201-213.

Wilczyński S (2004) The pointer and exceptional years in assessment of relationships "radial growth-climate". Sylwan 5: 30-40.

Wilczyński S \& Szymański N (2014) Pointer years of Norway spruce in the Western Beskidy Mountains (southern Poland). Sylwan 158(12): 883-892.

Zielski A (1997) Uwarunkowania środowiskowe przyrostów radialnych sosny zwyczajnej (Pinus sylvestris L.) w Polsce Północnej na podstawie wielowiekowej chronologii. Wydawnictwo Naukowe Uniwersytetu Mikołaja Kopernika w Toruniu. 